\title{
Yield and Quality of Lettuce, Pumpkin, and Watermelon Varieties Grown Under Five Soil Management Practices
}

\author{
George Fouad Antonious 1, *, Mohammad Hasan Dawood², Eric Todd Turley ${ }^{1}$, \\ Rance Bradley Paxton ${ }^{1}$ \\ ${ }^{1}$ Division of Environmental Studies, College of Agriculture, Community and the Sciences, Kentucky State University, Frankfort, USA \\ ${ }^{2}$ Department of Horticulture and Landscape, College of Agriculture, University of Kufa, El-Najaf, Iraq
}

\section{Email address:}

george.antonious@kysu.edu (G. F. Antonious)

${ }^{*}$ Corresponding author

\section{To cite this article:}

George Fouad Antonious, Mohammad Hasan Dawood, Eric Todd Turley, Rance Bradley Paxton. Yield and Quality of Lettuce, Pumpkin, and Watermelon Varieties Grown Under Five Soil Management Practices. International Journal of Applied Agricultural Sciences.

Vol. 7, No. 1, 2021, pp. 57-65. doi: 10.11648/j.ijaas.20210701.15

Received: January 12, 2021; Accepted: January 19, 2021; Published: February 9, 2021

\begin{abstract}
A field experiment was conducted to investigate the impact of five soil treatments: municipal sewage sludge (SS), horse manure (HM), chicken manure (CM), vermicompost (Vermi), and no-mulch (NM) native soil on the yield and quality of three lettuce, Lactuca sativa varieties (Romaine, Bibb, and Butterhead), three watermelons varieties (Sugar Baby, Crimson, and Charleston Grey), and three pumpkin varieties (Renegade, Howden, and Gumdrop). The objectives were to assess plant yield and quality responses to different amendments and soil urease, invertase, acid and alkaline phosphatase activity. At maturity, heads and fruits were harvested, weighed, and graded according to the USDA grades into Fancy, U.S. No. 1 and U.S. No. 2. Overall lettuce yield obtained from SS and CM amended soils was significantly greater (783 and $772 \mathrm{~g} \mathrm{head}^{-1}$, respectively) compared to Vermi amended soil $\left(663 \mathrm{~g} \mathrm{head}^{-1}\right)$. Yield obtained from lettuce variety Romaine was superior $(1.2$ $\left.\mathrm{kg} \mathrm{head}^{-1}\right)$ compared to Bibb and Butterhead varieties $\left(0.51\right.$ and $0.49 \mathrm{~kg} \mathrm{head}^{-1}$, respectively). Watermelons yield obtained from $\mathrm{CM}$ treatment was significantly greater $\left(4.49 \mathrm{~kg}\right.$ fruit $\left.{ }^{-1}\right)$ than that of $\mathrm{NM}$ control treatment $\left(3 \mathrm{~kg}\right.$ fruit $\left.{ }^{-1}\right)$. In addition, variety Charleston Grey produced the greatest fruit weight $\left(4.9 \mathrm{~kg}\right.$ fruit $\left.^{-1}\right)$ compared to Crimson and Sugar Baby (3.26 and $3.06 \mathrm{~kg}$ fruit $^{-1}$, respectively). Pumpkin yield obtained from SS treatment was significantly greater $\left(4.4 \mathrm{~kg}\right.$ fruit $\left.^{-1}\right)$ than that of NM treatment $\left(3.6 \mathrm{~kg}\right.$ fruit $\left.^{-1}\right)$. Pumpkin variety Howden produced the greatest pumpkin fruit weight $\left(4.6 \mathrm{~kg}\right.$ fruit $\left.{ }^{-1}\right)$ compared to Renegade and Gumdrop varieties (4.1 and $3.3 \mathrm{~kg}$ fruit ${ }^{-1}$, respectively). Soil properties fluctuated among treatments. The $\mathrm{NO}_{3}$ $\mathrm{N}$ values were greater in $\mathrm{HM}$ and Vermi treatments, whereas $\mathrm{NH}_{4}-\mathrm{N}$ was greater in $\mathrm{SS}$ and $\mathrm{CM}$ treatments compared to the control. No significant differences were found in phosphorus content among treatments. Concentrations of K and C (557 and $1230 \mu \mathrm{g}$ g-1 dry soil, respectively) were significantly greater in Vermi compared to the control treatments (336 and $1091 \mu \mathrm{g} \mathrm{g}-$ 1 dry soil, respectively). Vermi increased soil urease activity compared to other treatments. All amendments tested increased soil invertase activity. Whereas CM increased alkaline phosphatase activity. These results combine information to crop producers looking for cost-effective organic fertilizers to meet the market needs.
\end{abstract}

Keywords: Sewage Sludge, Chicken Manure, Horse Manure, Vermicompost, Soil Enzymes

\section{Introduction}

The aim in organic farming is to use of the least disruptive environmental practices to biological, chemical and physical processes, such as intercropping systems, biological pest control, evade the use of synthetic agrochemicals, maintain biodiversity and soil fertility, sequester soil organic carbon and nitrogen, and addition of animal manures to native agricultural soil to increase soil water holding capacity, cation exchange capacity, reduce soil bulk density and enhance soil beneficial microorganisms. The production of organic waste, such as municipal solid waste (MSW) and animal manures is continuously increasing worldwide due to the global urbanization of society and increase in farm coverage. Soil amendments, such as MSW and animal 
manures (chicken manure, horse manure, and vermicompost or worm casting) are contributors of soil fertility due to their microbial and nutrient content. Soil quality is significantly dependent on soil biology in which microorganisms play energetic parts in soil fertility and crop production through enzymatic activity, organic matter decomposition, and nutrient cycling. Animal manure is a useful fertilizer for improving soil quality and nutrient status and for reducing dependence on synthetic inorganic fertilizers at low-cost to limited resource farmers [1].

In agricultural production systems, lettuce, Lactus sativa L. is one of the most widely consumed vegetable worldwide [2] due to its good taste, low price, and high nutritive value, fiber, and mineral addition to a diet. Bioactive substances in plants strongly depend on the cultivar characteristics, climate conditions, seasonal changes, and plant maturity [3]. However, the impact of soil amendments, such as animal manures has not been completely investigated with respect to crop varietal selection under the growing global demand for food and the need to increase crop production through specific agricultural fertilization practices, such as restoring of soil organic matter by the addition of organic fertilizers that allow the recovery of soil fertility. Watermelon, Citrullus lanatus L., a member of the Cucurbitaceae family, is a favorite summertime treat. It is both marketed directly and via wholesale with production scattered throughout the state of Kentucky (USA). Some areas of concentrated watermelon production in Kentucky include Allen, Casey, Christian, Daviess, Hart, Lincoln, Scott, Taylor, and Todd Counties. Watermelons varietal selection continues to be a primary consideration for farmers so they can make decisions to suit their needs in yield, disease resistance, and buyers' needs for fruit quality and appearance. Based on an individual's market channels, consumer needs may differ for varieties [4]. Pumpkin, Cucurbita pepo L. is traditionally grown in the northeast U.S. whereas the southeast climate increases the risk of disease and insect pressures. Pumpkin is an economically important crop grown for fall decoration in the U.S. and is traditionally carved and illuminated for display during the holiday of Halloween. Over 20,000 ha of pumpkins were planted in the U.S. with a farm value of $\$ 145$ million [5].

Crop responses to different animal manures used for growing vegetables differ considerably [6]. Maerere et al. [7] reported that most studies on utilization of animal manure have largely concentrated on crop yield responses with very little attempts to relate such responses with crop varieties and soil enzymes activity following animal manure application. Animal manures applied to soils have a variety of soil microorganisms that release a variety of enzymes responsible for breaking down complex forms of organic materials [1] as well as $\mathrm{P}, \mathrm{K}, \mathrm{Ca}, \mathrm{Mg}$ and $\mathrm{NO}_{3}$ compared to soils to which inorganic fertilizers have been applied [8, 9]. Chicken manure $(\mathrm{CM})$ is a cheap natural product that is locally available to organic vegetable growers for use to replace inorganic fertilizers which are relatively expensive and can potentially contaminate natural water resources. In addition, the increased size and frequent clean-up of many poultry operations make poultry manure available in sufficient quantities and on timely basis to supply most fertilizer needs. Regarding biosolids, such as sewage sludge (SS) the world generates 1.3 billion tons of municipal solid waste (biosolids) annually. By 2025, the world could generate 2.2 billion tons of biosolids per year [10].

Synthetic commercial fertilizers contain nutrients designed to be rapidly released to growing plants once applied to soil. This fast availability to crops increases nutrient mobility into surface runoff and infiltration water following rainfall events, whereas the organic $\mathrm{N}$ fraction in biosolids, such as SS, reduces the availability and mobility of nutrients into runoff and infiltration water [11], due to SS slow release of nutrients. SS has shown promise for growing many field crops, such as sorghum, maize, and forage grasses and vegetables, such as cucumbers, cabbage, lettuce, potatoes, and beans $[12,13]$. Regarding horse manure (HM), approximately $75 \%$ of horse farms utilize or store HM onsite as grasslands and this is the primary means of disposal. $\mathrm{HM}$ is a good source of $\mathrm{N}$ because of its suitable $\mathrm{C} / \mathrm{N}$ ratio [14] that can be explored for land farming. In addition, the interaction of earthworms with microorganisms and other fauna within a decomposer, especially designed for incubation process, produces a product known as vermicompost. Vermicompost (Vermi or worm castings) accelerates the stabilization of soil organic matter and its physical and biochemical properties. The NPK elements and $\mathrm{C} / \mathrm{N}$ ratio of Vermi revealed its agronomic value as organic soil conditioner. Many investigators reported that Vermi has important properties that can be explored as a new technology for converting organic wastes into a product rich in plant nutrients [15]. Accordingly, the use of CM, SS, HM, and Vermi as soil amendments in land farming provides a useful means of waste disposal, and a feasible method for improving soil fertility and its physical properties.

The main objectives of this investigation were to: 1) assess the impact of four soil amendments (SS, CM, HM, Vermi) and native soil on the yield and quality of three lettuce, Lactuca sativa varieties (Romaine, Bibb, and Butterhead), three watermelons varieties (Sugar Baby, Crimson, and Charleston), and three pumpkin varieties (Renegade, Howden, and Gumdrop) and 2) investigate the impact of soil amendments on soil urease, invertase, and phosphatase activity in field grown vegetables.

\section{Materials and Methods}

\subsection{Field Experiment}

A field experiment at the University of Kentucky Horticulture Research Farm (Fayette County, KY, USA) was established in a randomized complete block design (RCBD). The Bluegrass-Maury Silty Loam soil of the plots used in this investigation has $2.2 \%$ organic matter and $\mathrm{pH} 6.1$. The soil texture has $56 \%$ silt, $38 \%$ clay, and $6 \%$ sand. The study area contained 135 plots. Each plot was $5 \times 4 \mathrm{ft}^{2}(152.4 \times$ 
$121.9 \mathrm{~cm}^{2}$ ). Plots $(5$ treatments $\times 3$ crops $\times 3$ varieties of each crop $\times 3$ replicates each) were planted with three varieties of lettuce, Lactus sativa; three varieties watermelon, Citrullus lanatus; and three varieties of pumpkin, Cucurbita pepo grown from seeds (Table 1) under greenhouse conditions.
Greenhouse seedlings were fertilized twice a week with 200 ppm Peters Professional (N20-P20-K20) fertilizer obtained from Martin's Produce Supplies (Fork Ridge Rd, Liberty, KY, USA).

Table 1. Seed sources of three varieties of lettuce, watermelon, and pumpkin plants grown at the University of Kentucky South Farm (Fayette County, Kentucky, USA).

\begin{tabular}{|c|c|c|c|c|}
\hline Plant & Latin Name & Variety & Seed Source & Address \\
\hline \multirow[t]{3}{*}{ Lettuce } & Lactus & Bibb (Bambi) & Johnny's Seed & Winslow, ME, USA \\
\hline & sativa $L$. & Butterhead (Adriana) & , & , \\
\hline & & Romaine (Sparx) & ” & , \\
\hline \multirow{3}{*}{ Watermelon } & Citrullus & Crimson Sweet & ” & , \\
\hline & lanatus $L$. & Sugar Baby & ” & , \\
\hline & & Charleston Grey & Anderson Farm & Lawrenceburg, KY, USA \\
\hline \multirow[t]{2}{*}{ Pumpkin } & Cucurbita & Renegade & Johnny's Seed & Winslow, ME, USA \\
\hline & & Howden & Johnny's Seed & Winslow, ME, USA \\
\hline
\end{tabular}

The soil treatments used in this study were: control treatment (NM native soil), sewage sludge (SS), horse manure (HM), chicken manure (CM), and vermicompost (Vermi). All soil amendments were applied at 5\% nitrogen (N) on dry weight basis to eliminate variations among soil treatments due to $\mathrm{N}$ content. SS was purchased from the Metropolitan Sewer District (Louisville, KY, USA), and CM was obtained from the Department of Animal and Food Sciences, University of Kentucky (Lexington, KY, USA). $\mathrm{HM}$ was obtained from the Kentucky horse park (Lexington, KY, USA) and Vermi (worm castings) was obtained from Worm Power (Montpelier, Vermont, USA). Amendments in each treatment (except the control treatment) were applied to native topsoil and rototilled to a depth of $15 \mathrm{~cm}$ of topsoil. Fifty-five days-old seedlings of lettuce and 36 days-old seedlings of pumpkins and watermelons varieties were planted in a freshly tilled soil at 18 inches $(45 \mathrm{~cm})$ in-row spacing in black plastic mulch and drip irrigated as needed. Weeding and other agricultural practices were applied regularly as needed. The plants were sprayed with the two pyrethroid insecticides esfenvalerate (Asana XL) and Baythroide XL ( $\beta$-cyfluthrin) [16] mixed with the fungicidebactericide Badge SC (16.8\% copper oxychloride $+15.4 \%$ copper hydroxide) obtained from Gowan Company (P. O. Box 5569 Yuma, AZ). Field spraying was carried out three times at seven days intervals. At maturity, lettuce heads and watermelon fruits were harvested, weighed, and classified according to the USDA grades into US Fancy, U.S. No. 1, U.S. No. 2, and culls [17, 18]. Individual lettuce heads were cut at the soil level, weighed, and graded for marketability according to U.S. Department of Agriculture standards [17]. Lettuce heads that were excessively damaged and or had leaf defects were classified as "cull". Cull head defects included bolted heads (flowered heads), or heads with a crumpling of the center, or heads exhibiting leaf-tissue damage [19]. Pumpkin fruits were harvested, weighed, and classified according to the USDA grades into U.S. No. 1, U.S. No. 2, and culls [20].

Based on head appearance, U.S. Fancy lettuce consists of heads which have similar varietal characteristics (head is not split or broken open, free from decay, rust spotting, no double heads on the same stem, free from injury by tip-burn, downy mildew, field freezing, discoloration, well-trimmed head, and not damaged by any other cause. U.S. No. 1 lettuce consists of heads which are fresh, green, not soft, not burst, free from decay, free from doubles, not damaged by any other cause, and fairly-well trimmed. U.S. No. 2 lettuce consists of heads which are not burst, free from decay, not seriously damaged by any other cause, and well-trimmed [17]. Lettuce culls are heads that are not marketable due to the presence of holes caused by disease and/or other damage. U.S. Fancy watermelon fruits are mature, fairly-well formed, not overripe, free anthracnose, decay, sunscald, whiteheart, and free from damage by any means. U.S. No. 1 watermelon consists of fruits which are mature, have similar varietal characteristics, fairly-well formed, not overripe, free from anthracnose, decay, sunscald, and free from damage by any means. U.S. No. 2 watermelon consists of mature fruits that are not overripe, not badly misshapen, free from anthracnose, decay, sunscald, and free from serious damage by any means [18]. Culls watermelons are fruits that are not marketable due to the presence of holes caused by disease and/or damage. U.S. No. 1 pumpkin consists of fruits which have varietal characteristics (shape, texture and color), well matured, not broken or cracked, free from soft rot or wet breakdown, free from damage by scars caused by rodents or other means, dry rot, freezing, dirt, disease, insects, or mechanical or other means. U.S. No. 2 pumpkin consists of fruits which have similar shape, texture and color, fairly well matured, not broken or cracked, free from soft rot or wet breakdown, free from serious damage by scars caused by rodents or other means, dry rot, freezing, dirt, disease, insects, mechanical or other means [20]. Culls pumpkins are fruits that are not marketable due to the presence of holes caused by disease and/or other damage.

\subsection{Soil Characteristics and Chemical Analysis}

Soil samples were collected after planting from each treatment to a depth of $15 \mathrm{~cm}$ (a zone of increased microbial 
and enzyme activity where soil and root make contact). Samples were collected using a core sampler (Clements Associates, Newton, IA) equipped with a plastic liner tubes of $2.5 \mathrm{~cm}$ i.d. for maintenance of sample integrity. Samples were air-dried at room temperature, passed through a $2 \mathrm{~mm}$ non-metallic sieve, and kept at $4^{\circ} \mathrm{C}$ up to $24 \mathrm{~h}$ before use. Soil samples collected from each plot $(n=3)$ were mixed with distilled water at 1:5 (w/v) ratio. Soil $\mathrm{pH}$ and electrical conductivity (EC) were measured using a hand-held portable combination (WTW Weilheim, Germany) of glass electrode with calibrated millivolt meter ( $\mathrm{pH}$ meter) and an EC meter that was standardized with a $\mathrm{KCl}$ solution. Soil urease activity was determined as described by Tabatabi and Bremner [21]. Invertase activity in soil was measured by the method described by Balasubramanian et al. [22]. Soil acid and alkaline phosphatase activities were assessed using the method developed by Tabatabai and Bremner [23]. Soil samples also were dried at $105^{\circ} \mathrm{C}$ for $24 \mathrm{~h}$ in an oven and manually grounded and sieved to pass through a $2 \mathrm{~mm}$ non- metal screen. To $1 \mathrm{~g}$ of each dry soil powder, $10 \mathrm{~mL}$ of concentrated nitric acid $\left(\mathrm{HNO}_{3}\right)$ was added, and the mixture allowed to stand overnight, then heated for $4 \mathrm{~h}$ at $125^{\circ} \mathrm{C}$ on a hot plate. Concentrations of metals in native soil and soil amendments were determined using inductively coupled plasma-mass spectrometer (ICP-MS) following the U.S. EPA method 6020a [24]. Properties of soil amendments and native soil of the experimental site are described in Table 2.

\subsection{Statistical Analysis}

Data of the yield of marketable lettuce heads, watermelons, and pumpkins fruits appearance were collected from the five treatments of each of the three cultivars of each crop. Data containing yield, quality of each variety, and soil treatments were statistically analyzed using analysis of variance (ANOVA) and the means were compared using Duncan's multiple range test (SAS Institute) [25] as shown in Table 3 .

Table 2. Properties of native soil and soil amended with sewage sludge and animal manures used for growing lettuce, watermelon, and pumpkin varieties at the University of Kentucky South Farm (Fayette County, Kentucky, USA).

\begin{tabular}{|c|c|c|c|c|c|}
\hline Soil Properties & Sewage Sludge & Chicken Manure & Horse Manure & Vermi-compost & Native Soil \\
\hline Soil-Water $\mathrm{pH}$ & $5.67 \pm 0.1 \mathrm{~b}$ & $6.20 \pm 0.3 \mathrm{a}$ & $5.64 \pm 0.1 \mathrm{~b}$ & $5.71 \pm 0.1 \mathrm{~b}$ & $6.1 \pm 0.3 \mathrm{a}$ \\
\hline $\mathrm{N}-\mathrm{NO}_{3}, \mathrm{ppm}$ & $20.1 \pm 3.5 \mathrm{c}$ & $18.3 \pm 9.2 \mathrm{~d}$ & $25.0 \pm 6.0 \mathrm{~b}$ & $37.3 \pm 11.8 \mathrm{a}$ & $20.7 \pm 4.5 \mathrm{c}$ \\
\hline $\mathrm{N}-\mathrm{NH}_{4}, \mathrm{ppm}$ & $29.7 \pm 17 b$ & $66.7 \pm 6.4 \mathrm{a}$ & $3.33 \pm 0.58 \mathrm{c}$ & $3.67 \pm 0.58 \mathrm{c}$ & $5.67 \pm 3.79 \mathrm{c}$ \\
\hline $\mathrm{P}, \mathrm{ppm}$ & $100.3 \pm 10.7 \mathrm{a}$ & $89.3 \pm 6.6$ a & $116.00 \pm 50 \mathrm{a}$ & $87.67 \pm 9.5 \mathrm{a}$ & $95.83 \pm 10.2 \mathrm{a}$ \\
\hline $\mathrm{K}, \mathrm{ppm}$ & $327.5 \pm 4.9 \mathrm{~d}$ & $483.8 \pm 74.8 \mathrm{~b}$ & $365.5 \pm 26 \mathrm{~cd}$ & $557.3 \pm 79.8 \mathrm{a}$ & $336.2 \pm 12.1 \mathrm{~d}$ \\
\hline $\mathrm{C}, \mathrm{ppm}$ & $1050.0 \pm 28 \mathrm{c}$ & $1160.8 \pm 51.0 \mathrm{~b}$ & $1067.2 \pm 23 . c$ & $1230.2 \pm 27.9 \mathrm{a}$ & $1091.7 \pm 22.2 \mathrm{c}$ \\
\hline $\mathrm{EC}, \mu \mathrm{S} \mathrm{cm} \mathrm{cm}^{-1}$ & $106.4 \pm 13 \mathrm{ab}$ & $95.83 \pm 14.61 \mathrm{~b}$ & $89.3 \pm 14.1 \mathrm{~b}$ & $122.3 \pm 8.59 \mathrm{a}$ & $94.4 \pm 13.1 \mathrm{~b}$ \\
\hline Urease & $956.3 \pm 165 b$ & $993 \pm 192 b$ & $805.8 \pm 130 \mathrm{c}$ & $1105.9 \pm 141 \mathrm{a}$ & $911.8 \pm 109 \mathrm{~b}$ \\
\hline Invertase & $3696.9 \pm 312 \mathrm{a}$ & $3736.1 \pm 339 \mathrm{a}$ & $3610 \pm 282 \mathrm{a}$ & $3970.3 \pm 272 \mathrm{a}$ & $3234.2 \pm 265 \mathrm{~b}$ \\
\hline Acid Phosphatase & $1435.4 \pm 107 \mathrm{a}$ & $1158.3 \pm 42 b$ & $1197.3 \pm 35 \mathrm{~b}$ & $1413.6 \pm 51 \mathrm{a}$ & $1354.9 \pm 79 \mathrm{a}$ \\
\hline Alkaline Phosphatase & $389.3 \pm 50 \mathrm{c}$ & $524.43 \pm 80 \mathrm{a}$ & $400.67 \pm 46 \mathrm{~b}$ & $309.38 \pm 45 \mathrm{c}$ & $427.62 \pm 60 \mathrm{~b}$ \\
\hline
\end{tabular}

Soil Urease activity was expressed as $\mu \mathrm{g} \mathrm{NH}_{4}-\mathrm{N}$ released $\mathrm{g}^{-1}$ dry soil. Invertase activity was expressed as $\mu \mathrm{g}$ glucose released $\mathrm{g}^{-1}$ dry soil. Acid and alkaline phosphatase were expressed as $\mu \mathrm{g}$ p-nitrophenol released $\mathrm{g}^{-1}$ dry soil.

Table 3. Analysis of variance (ANOVA) of the effect of soil treatments on lettuce, pumpkin, and watermelon yield and quality.

\begin{tabular}{|c|c|c|c|c|c|c|c|}
\hline Dependent Variable & Crop & Variable & Sum of Squares & df & Mean-Square & F-Test & $p$-Value \\
\hline \multirow{8}{*}{ Weight (gram) } & \multirow{3}{*}{ Lettuce } & Head grade & 312419 & 3 & 104139 & 3.69 & $<.012 * *$ \\
\hline & & Soil treatment & 426255 & 4 & 106563 & 3.78 & $0.0054 * * *$ \\
\hline & & Variety & $2.42 \mathrm{e}+7$ & 2 & $1.21 \mathrm{e}+7$ & 429 & $<.0001 * * *$ \\
\hline & \multirow{3}{*}{ Pumpkin } & Fruit grade & 34.57 & 2 & 17.28 & 15.52 & $<.0001 * * *$ \\
\hline & & Soil treatment & 13.53 & 4 & 3.38 & 3.04 & $0.0184 * *$ \\
\hline & & Variety & 58.56 & 2 & 29.28 & 26.28 & $<.0001 * * *$ \\
\hline & \multirow{2}{*}{ Watermelon } & Fruit grade & 447.88 & 3 & 149.30 & 58.18 & $<.0001 * * *$ \\
\hline & & Variety & 139.58 & 2 & 69.78 & 27.20 & $<.0001 * * *$ \\
\hline
\end{tabular}

**, *** indicate statistical significance at $P<0.05$ and 0.01 , respectively.

\section{Results and Discussion}

Crop varietal selection type (Figure 1) and properties of soil amendments (Table 2) are critical choice for growers who are seeking greater marketable vegetable yield at affordable cost. Overall lettuce yields obtained from SS and CM amended soils were significantly greater (783 and $772 \mathrm{~g}$ head $^{-1}$, respectively) compared to Vermi amended soil (663 g head $\left.{ }^{-1}\right)$. Whereas no significant differences $(P \geq 0.05)$ were found between HM and NM native soil (Figure 2A). Using the USDA scale of lettuce grades, U.S. No. 1 grade had the greatest fruit weight compared to U.S. No. 2 and Fancy (Figure 2B). In addition, regardless of soil treatments, yield obtained from variety Romain was superior $\left(1.2 \mathrm{~kg}\right.$ head $\left.{ }^{-1}\right)$ compared to Bibb and Butterhead varieties $(0.51$ and $0.49 \mathrm{~kg}$ head $^{-1}$, respectively) (Figure 2C). We recommended the use of variety Romain for growing lettuce in soil amended with SS for greater head yield. Watermelons results revealed that yield obtained from CM treatment was significantly greater (4.49 $\mathrm{kg}$ fruit $\left.{ }^{-1}\right)$ compared to the control treatment $(3 \mathrm{~kg}$ 
fruit $^{-1}$ ) (Figure 3A).

Based on fruit appearance and using the USDA of watermelons grades, Fancy had the greatest fruit weight compared to U.S. No. 1 and U.S. No. 2 (Figure 3B). In addition, watermelon variety Charleston Grey produced the greatest fruit weight $\left(4.9 \mathrm{~kg}_{\text {fruit }}{ }^{-1}\right)$ compared to Crimson Sweet and Sugar Baby varieties (3.26 and $3.06 \mathrm{~kg}_{\text {fruit }}{ }^{-1}$, respectively) (Figure 3C). Accordingly, we recommended the use of variety Charleston Grey for growing watermelons in soil amended with $\mathrm{CM}$ for greater yield and fruit quality. Pumpkin results revealed that yield obtained from SS treatment was significantly greater $\left(4.4 \mathrm{~kg}_{\text {fruit }}{ }^{-1}\right)$ than that of other soil amendments tested (CM, Vermi, and HM) and no-mulch native soil $\left(3.6 \mathrm{~kg}_{\text {fruit }}{ }^{-1}\right)$ (Figure 4A). Using the USDA pumpkin grades, U.S. No. 1 and U.S. No. 2 grades were significantly equal in fruit weight compared to culls (Figure 4B). In addition, variety Howden produced the greatest fruit weight $\left(4.6 \mathrm{~kg}_{\text {fruit }}{ }^{-1}\right)$ compared to Renegade and Gumdrop pumpkin varieties (4.1 and $3.3 \mathrm{~kg}$ fruit ${ }^{-1}$, respectively) (Figure 4C). Accordingly, we recommended the use of variety Howden for growing pumpkin in soil amended with SS for greater fruit yield and quality.

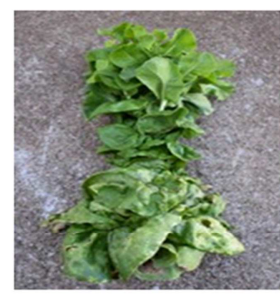

Bibb (Bambi)

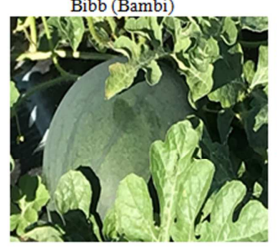

Sugar Baby

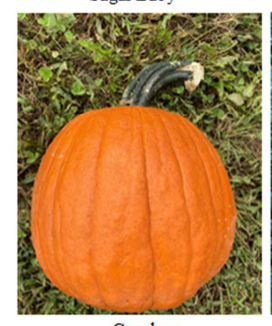

Gundrop

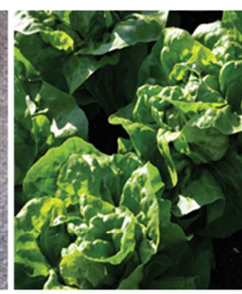

Butterhead (Adriana)

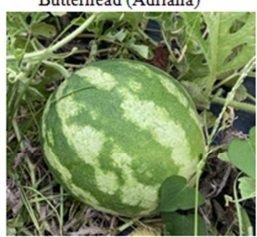

Crimson Sweet

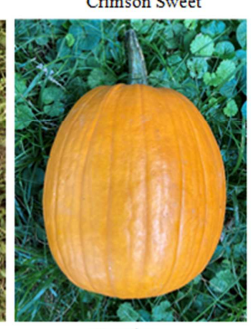

Howden

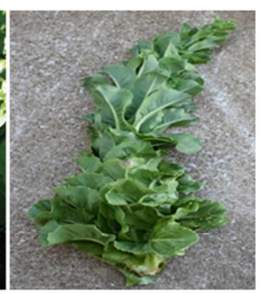

Romaine (Sparx)

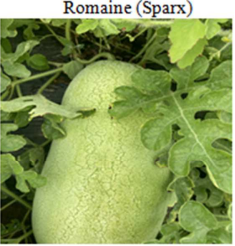

Charleston Grey

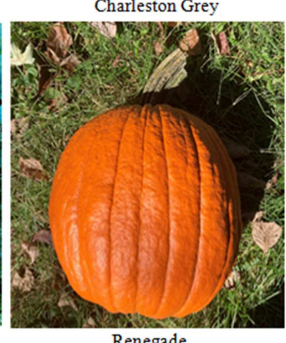

Figure 1. Lettuce (upper pictures), watermelons (middle pictures), and pumpkins (lower pictures) varieties grown at the University of Kentucky South Farm (Fayette County, Kentucky, USA).

Regarding the growing conditions, the highest $\mathrm{pH}$ value of 6.2 among soil amendments was recorded in $\mathrm{CM}$ amended soil (Table 2), which was significantly equal to $\mathrm{pH}$ of the native soil used in this investigation. $\mathrm{pH}$ is a good indicator of soil quality and a neutral $\mathrm{pH}$ is usually preferred as most nutrients within the manure will be bioavailable in that range. Ravindran et al. [26] reported that plant growth is optimal at a $\mathrm{pH}$ between 5.8 and 6.5 depending on plant species, making the $\mathrm{CM}$ an appropriate soil amendment. However, the effects of any soil amendment most likely depend on the soil type and application rates. Dikinya and Mufwanzala [27] reported that a significant decrease in the growth of spinach, $S$. oleracea plants grown in different soil types was found when poultry manure was applied to soil beyond the $20 \%$ rate, indicating the negative impact of $\mathrm{CM}$ on spinach yield with increasing application rate. High EC values of animal manures indicate high salt concentrations which can result in disruption of soil physical properties, osmotic pressure and ion toxicity, which affect crop germination and physiological processes in plants [28]. Table 2 shows that the EC of manures varied significantly and was high in Vermi and low in $\mathrm{CM}$, making $\mathrm{CM}$ a suitable fertilizer for direct soil application. However, the EC (soluble salts) levels can vary considerably, depending on feedstock and amendment type and this might explain the wide variations observed in soil enzymes activity and crop yield varieties responses obtained in this study.
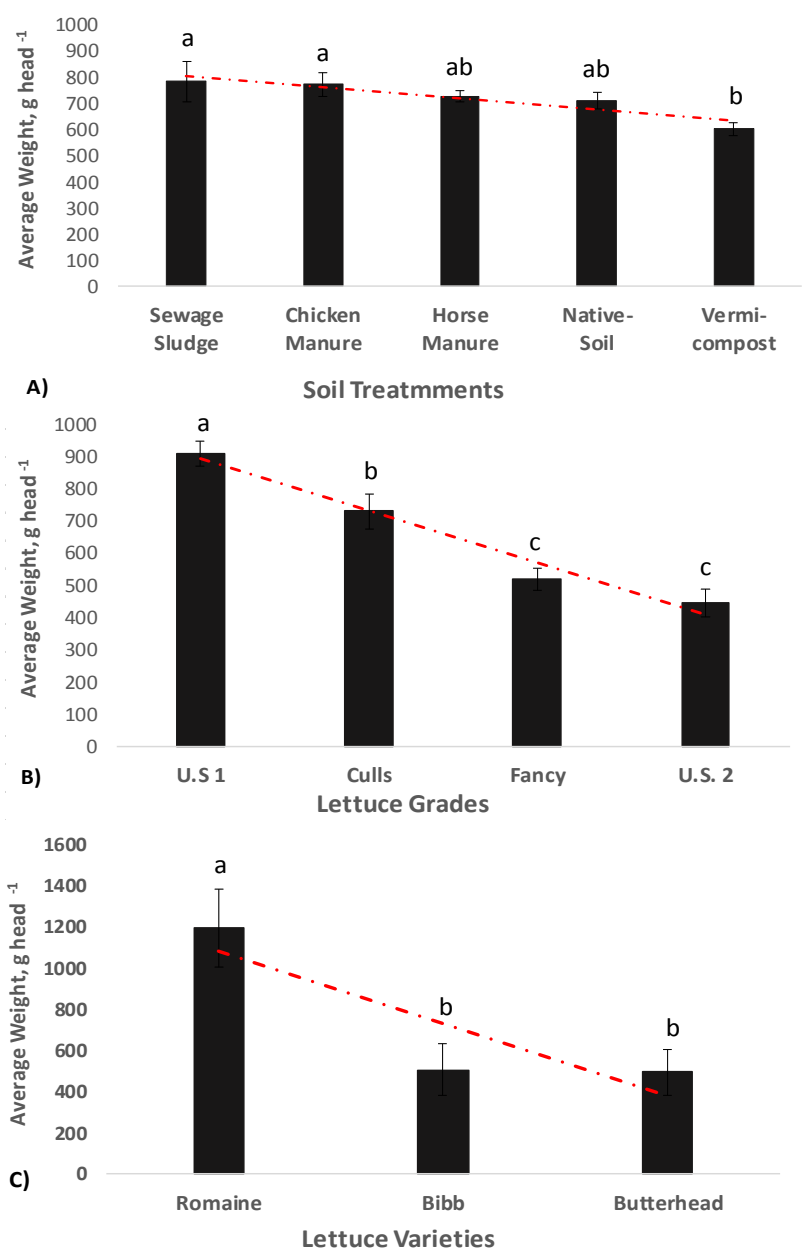

Figure 2. Average weight \pm standard deviation of lettuce heads collected at harvest from plants grown under five soil management practices (A), USDA standard grades of heads $(B)$, and weight of heads obtained from three lettuce varieties (C). Statistical comparisons were carried out among soil treatments/crop grades or varieties. Bars accompanied by different letter (s) in each graph indicate significant differences $(P \leq 0.05)$ using Duncan's multiple range test. 
Soil microorganisms in amendments used in this investigation secrete a variety of extracellular enzymes. These enzymes decompose complex forms of organic matter in soil releasing the $\mathrm{C}-, \mathrm{N}$-, and P-elements, the nutrients needed for plant growth released due to soil invertase, urease, and phosphatase activity, respectively. Soil urease originates mainly from plants [29] and soil microorganisms [30] to hydrolyze urea fertilizers into $\mathrm{NH}_{3}$ and $\mathrm{CO}_{2}$. Soil invertase is the enzyme that splits sucrose into its two components, glucose and fructose. Invertase is available in microorganisms, animals, and plants [31]. The activities of urease and invertase are important in soil for releasing simple $\mathrm{N}$ and $\mathrm{C}$ sources for the growth and multiplication of soil microorganisms. Phosphatases transform complex organic phosphate esters to orthophosphate ions [32, 33] accessible to the plant uptake, and thus represent an important link between naturally unavailable and bioavailable $\mathrm{P}$ pools in the soil. Phosphatases are abundant in soil and secreted by microorganisms in reply to low levels of inorganic phosphates.

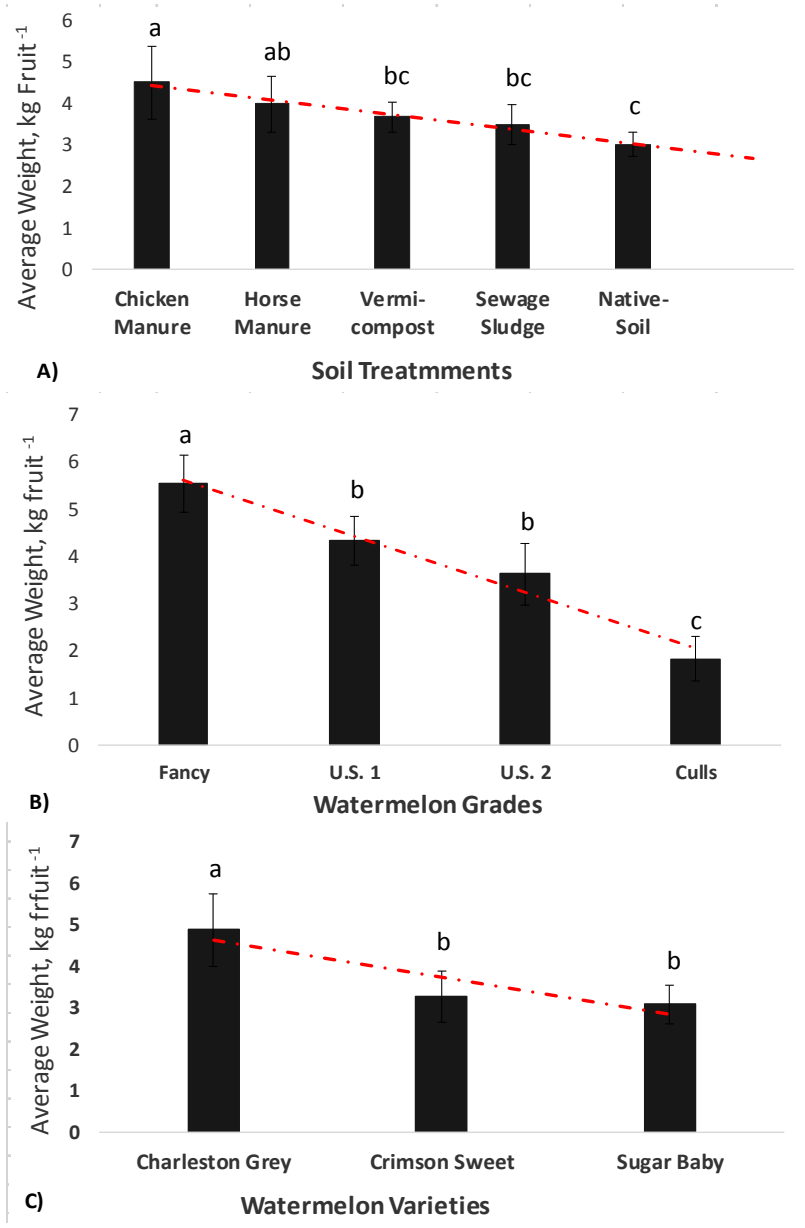

Figure 3. Average weight \pm standard deviation of watermelon fruits collected at harvest from plants grown under five soil management practices (A), USDA standard grades of fruits (B), and weight of fruits obtained from three watermelon varieties (C). Statistical comparisons were carried out among soil treatments/crop grades or varieties. Bars accompanied by different letter (s) in each graph indicate significant differences $(P \leq 0.05)$ using Duncan's multiple range test.
Table 2 also revealed that Vermi increased soil urease activity compared to CM, HM, and the control treatment (native soil). Data also showed a significant increase $(P \leq 0.05)$ in soil invertase activity after the addition of SS, $\mathrm{CM}, \mathrm{HM}$, and Vermi compared to the control treatment. On the contrary, CM and HM reduced acid phosphatase activity compared to the control treatment. Whereas significant rises in alkaline phosphatase activity were found after the addition of CM to native soil. Variations in amendment type and composition have a great impact on the soil microbial community and secreted enzymes. Animal manures or even agricultural soils may contain enzyme inhibitors. Soil contaminated with trace metals for example inhibits soil enzyme activities. Our results revealed that Vermi was superior in increasing soil urease activity $(P \leq 0.05)$ compared to the NM control treatment. All amendments tested in this investigation promoted invertase activity. SS and Vermi did not impact acid phosphatase activity, whereas CM and HM reduced acid phosphatase activity, whereas CM maximized soil alkaline phosphatase activity. Variations in soil enzymes activity might be due to the different characteristics of each of the amendments investigated, such as variations in their ability in absorbing and retaining water molecules that impact microbial survival and secretions. In addition, pharmaceutical substances used to treat farm animals do not metabolize completely within their body, they excrete in animal urine and feces either in their native form or as metabolites [34]. Accordingly, the increased fertilization of farmlands with organic fertilizers such as municipal SS, $\mathrm{CM}$, and HM may contribute to the introduction of antibiotics, heavy metals, and hormones into the soil, and this might be the cause of the fluctuation in some of the soil enzymes activity. Soil amendments differed significantly in their chemical composition which in turns pointed to the need for further investigation on the analysis of its trace metals composition when applied directly to agricultural soil. CM, which is the most abundant poultry manure, is a mixture of feces, waste feed, feather and bedding material, and essential plant nutrients making it an organic source of nutrients [26]. Organic amendments such as poultry manure are getting more awareness for use as organic fertilizers due to the escalating expense of inorganic fertilizers. However, the use of organic amendments has created unintended disposal problem to the soil, where it poses environmental challenges like eutrophication, air pollution, emission of greenhouse gasses and production of phytotoxic substances [35, 36]. Kao et al [37] reported that the addition of biosolids enriched in heavy metals reduced microbial biomass and soil microbial activity which have great impact on plant growth and crop yield. Accordingly, in addition to the positive impact of soil amendments, it is important to characterize their composition before direct application to agricultural soil. 


\section{Conclusion}

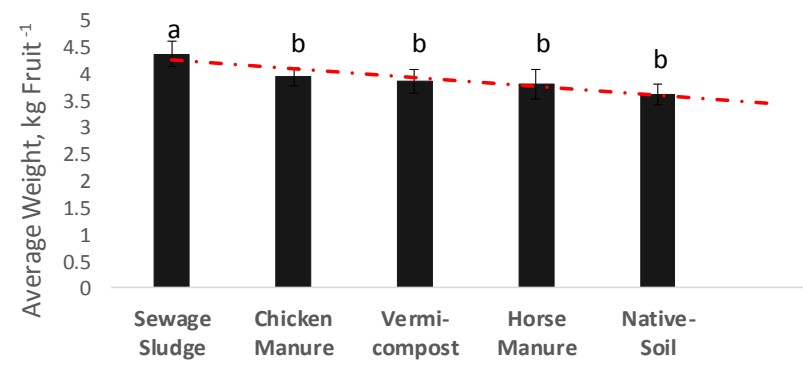

A)

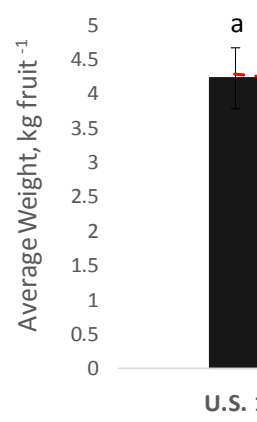

B)

C)
Soil Treatmments
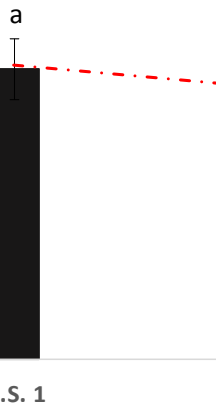

(1)

Pumpkin Grades

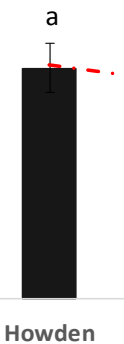

Howden

b

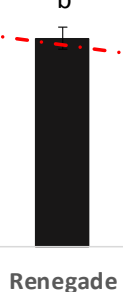

Renegade

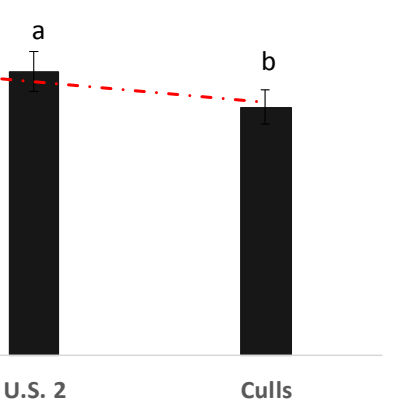

Pumpkin Varieties

Figure 4. Average weight \pm standard deviation of pumpkin fruits collected at harvest from plants grown under five soil management practices (A), USDA standard grades of fruits (B), and weight of fruits obtained from three pumpkin varieties (C). Statistical comparisons were carried out among soil treatments/ crop grades or varieties. Bars accompanied by different letter in each graph indicate significant differences $(P \leq 0.05)$ using Duncan's multiple range test.

Crop varietal responses to different soil amendments differed considerably. Overall lettuce results revealed that yield obtained from SS treatment was significantly greater $\left(783 \mathrm{~g} \mathrm{head}^{-1}\right)$ than that of Vermi treatment $\left(663 \mathrm{~g} \mathrm{head}^{-1}\right)$. In addition, variety Romaine produced the greatest head weight $\left(1.2 \mathrm{~kg}\right.$ head $\left.^{-1}\right)$ compared to Bibb and Butterhead varieties (0.51 and $0.49 \mathrm{~kg} \mathrm{head}^{-1}$, respectively). Using the USDA of lettuce grades, U.S. No. 1 grade had the greatest head weight compared to U.S. No. 2 and Fancy. Watermelons results revealed that the average fruit weight obtained from $\mathrm{CM}$ treatment was significantly greater $\left(4.49 \mathrm{~kg}_{\text {fruit }}{ }^{-1}\right)$ than that of control treatment $\left(3 \mathrm{~kg}\right.$ fruit $\left.{ }^{-1}\right)$. In addition, variety Charleston Grey produced the greatest watermelon fruit weight $\left(4.9 \mathrm{~kg}_{\text {fruit }}{ }^{-1}\right.$ ) compared to Crimson Sweet and Sugar Baby varieties (3.26 and $3.06 \mathrm{~kg}_{\text {fruit }}{ }^{-1}$, respectively). Using the USDA of watermelons grades, Fancy had the greatest fruit weight compared to U.S. No. 1, U.S. No. 2. Pumpkin results revealed that fruit weight obtained from SS

treatment was significantly greater $\left(4.4 \mathrm{~kg}_{\text {fruit }}{ }^{-1}\right)$ than that of other treatments. In addition, variety Howden produced the greatest fruit weight $\left(4.6 \mathrm{~kg}\right.$ fruit $\left.{ }^{-1}\right)$ compared to Renegade and Gumdrop varieties (4.1 and $3.3 \mathrm{~kg}_{\text {fruit }}{ }^{-1}$, respectively). Using the USDA pumpkin grades, U.S. No. 1 grade had the greatest fruit weight compared to U.S. No. 2. We recommended the use of SS for growing marketable Romaine lettuce and Howden pumpkins. Whereas CM is recommended for growing Charleston Grey watermelons at little or no fertilizer cost to limited resource farmers. The results of the present investigation indicated that not all the amendments tested promoted soil enzymes activity. A significant increase $(P \leq 0.05)$ in urease activity was found in Vermi treatments, all amendments tested increased invertase activity, whereas CM increased alkaline phosphatase activity. Our future objective will include 1) a complete analysis of each soil amendment for composition of trace metals, nutrients, antibiotics and 2) use of a mixture of SS and CM amendments to investigate their potential impact on increasing soil enzymes activity, crop yield, and fruit quality characteristics.

\section{Authors Contributions}

G. F. A. designed the study, conducted the laboratory soil analysis, and wrote the manuscript. E. T. T. and R. B. P. conducted the field experiment and M. H. D. conducted the statistical analysis.

\section{Conflicts of Interest}

The authors declare that they have no conflict of interest.

\section{Acknowledgements}

We thank Steve Diver and his farm crew at the University of Kentucky South Farm for maintaining the field plots. This investigation was supported by a grant from the United States Department of Agriculture, National Institute of Food and Agriculture (USDA/NIFA) to Kentucky State University under agreement No. KYX-10-18-65P Accession 1017900.

\section{References}

[1] Antonious, G. F., Turley, E. T., and Dawood, M. (2020). Monitoring soil enzymes activity before and after animal manure application. J. of Agriculture, 10, 166.

[2] Kim, M. J., Moon, Y., Tou, J. C., Mou, B., and Waterland, N. L. (2016). Nutritional value, bioactive compounds and health benefits of lettuce (Lactuca sativa L.). Journal of Food Composition and Analysis, 49, 19-34.

[3] Coria-Cayupán, Y. S., Sánchez de Pinto, M. I., and Nazareno, M. A. (2009). Variations in Bioactive Substance Contents and Crop Yields of Lettuce (Lactuca sativa L.) Cultivated in Soils with Different Fertilization Treatments. Journal of Agricultural and Food Chemistry, 57 (21), 10122-10129. 
[4] Saha, S. K., Snyder, J., Smigell, C, and Strang, J. (2016). Fruit and Vegetable 2016 Annual Research Report. University of Kentucky College of Agriculture, Food and Environment Cooperative Extension Service. PR-721. https://issuu.com/garypalmer7/docs/pr721.

[5] LaPlant, K. E., Wyatt, L. E., Moriarty, G., Fink-Brodnicki, M., Jahn, M., and Mazourek, M. (2016). Powdery Mildewresistant Pumpkin Inbred Lines. HortScience, 51 (10), 1297 1300.

[6] Azeez, J. O., Van Averbeke, W., \& Okorogbona, A. O. M. (2010). Differential responses in yield of pumpkin (Cucurbita maxima L.) and nightshade (Solanum retroflexum Dun.) to the application of three animal manures. Bioresource Technology, 101 (7), 2499-2505.

[7] Maerere, A. P., Kimbi, G. G., Nonga, D. L. M. (2001). Comparative effectiveness of animal manures on soil chemical properties, yield and root growth of amaranthus (Amaranthus cruentus L.). Afr. J. Sci. Technol. 1 (4), 14-21.

[8] Edmeades, D. C. (2003). The long-term effects of manures and fertilisers on soil productivity and quality: a review. Nutr. Cycl. Agroecosyst. 66, 165-180.

[9] Herencia, J. F., Ruiz-Porras, J. C., Melero, S., Garcia-Galavis, P. A., Morillo, E., Maqueda, C. (2007). Comparison between organic and mineral fertilization for soil fertility levels, crop macronutrient concentrations, and yield. Agron. J. 99, 973983.

[10] Moya, D.; Aldás, C.; López, G.; Kaparaju, P. (2017). Municipal solid waste as a valuable renewable energy resource: A worldwide opportunity of energy recovery by using Waste-To-Energy Technologies. Energy Procedia, 134, 286-295.

[11] Antonious, G. F. (2015). Reducing herbicides in agricultural runoff and seepage water. Book chapter-1, pages 3-34. In: Herbicides, Physiology of Action, and Safety, ISBN 978-95351-4413-7. November 2015, edited by Andrew Price, Linda Sarunaite, and Jessica Kelton. Published by Intech, Janeza Trdine 9, 51000 Rijeka, Croatia.

[12] Shiralipour, A.; McConnell, D. B.; Smith, W. H. (1992). Physical and chemical properties of soils as affected by municipal solid waste compost application. Biomass Bioenergy 1992a, 3, 261-266.

[13] Shiralipour, A.; McConnell, D. B.; Smith, W. H. (1992). Uses and benefits of MSU compost: A review and assessment. Biomass and Bioenergy 1992b, 3, 267-279.

[14] Mönch-Tegeder M., Lemmer A., Oechsner H. (2014). Enhancement of methane production with horse manure supplement and pretreatment in a full-scale biogas process. Energy, 73: 523-530.

[15] Yadav A, Gupta R, Garg VK. (2013). Organic manure production from cow dung and biogas plant slurry by vermicomposting under field conditions. International Journal of Recycling of Organic Waste in Agriculture., 2 (21): 3-7.

[16] Rudolph, R., Pfeufer, E., Bessin R., Wright, S, Strang, J. (2020). Vegetable Production Guide for Commercial Growers. University of Kentucky College of Agriculture, Food and Environment Cooperative Extension Service. http://www2.ca.uky.edu/agcomm/pubs/id/id36/id36.pdf

[17] United States Standards for Grades of Field Grown Leaf
Lettuce, August 25, 2006. https://www.ams.usda.gov/gradesstandards/field-grown-leaf-lettuce-grades-and-standards.

[18] United States Standards for Grades of Watermelons, March 23, 2006.

https://www.ams.usda.gov/sites/default/files/media/Watermel on_Standard\%5B1\%5D.pdf.

[19] Dufault, R. J., Ward, B., \& Hassell, R. L. (2009). Dynamic relationships between field temperatures and romaine lettuce yield and head quality. Scientia Horticulturae, 120 (4), 452-459.

[20] United States Standards for Grades of Pumpkins, October 13, 1983. https://www.ams.usda.gov/grades-standards/fall-andwinter-type-squash-and-pumpkin-grades-and-standards

[21] Tabatabi, M. A.; Bremner, J. M. Assay of urease activity in soils. Soil Biol. Biochem. 1972, 4, 479-487.

[22] Balasubramanian, D.; Bagyaraj, D. J.; Rangaswami, G. Studies on the influence of foliar application of chemicals on the microflora and certain enzyme activities in the rhizosphere of Eleusine coracana Gaertn. Plant Soil 1970, 32, 198-206.

[23] Tabatabai, M. A.; Bremner, J. M. Use of p-nitrophenol phosphate for assay of soil phosphatase activity. Soil Biol. Biochem. 1969, 1, 301-307.

[24] EPA Method 6020a: Inductively Coupled Plasma -Mass Spectrometry; USEPA: Washington, DC, USA, 1998.

[25] SAS Institute Inc. SAS/STAT Guide, Version 9.4 SAS 2016 Inc., Campus Drive, Cary, NC 27513.

[26] Ravindran, B., Mupambwa, H. A., Silwana, S., Mnkeni, P. N. (2017). Assessment of nutrient quality, heavy metals and phytotoxic properties of chicken manure on selected commercial vegetable crops. Heliyon, 3 (12), e00493.

[27] Dikinya, O. and Mufwanzala, N. (2010) Chicken ManureEnhanced Soil Fertility and Productivity: Effects of Application Rates. Journal of Soil Science and Environmental Management, 1, 46-54.

[28] Cho, W. M., Ravindran, B., Jung Kon, K., Gwang-Hwa, J., Dong-Jun, L., Dong-Yoon., C. (2017). Nutrient status and phytotoxicity analysis of goat manure discharged from farms from South Korea. Environ. Technol., 38 (9), pp. 1191-1199.

[29] Polacco, J. C. (1977). Is nickel a universal component of plant ureases? Plant Sci. Lett., 10, 249-255.

[30] Mobley, H. L. T.; Hausinger, R. P. (1989). Microbial urease: Significance, regulation, and molecular characterization. Microbiol. Rev., 53, 85-108.

[31] Alef, L. K.; Nannipieri, P. Methods in Soil Microbiology and Enzyme Activities; Academic Press/Harcourt Brace and Company Publishers: London, UK, 1995; pp. 225-230.

[32] Alef, K.; Nannipieri, P.; Trasar-Cepeda, C. Phosphatase activity. In Methods in Applied Soil Microbiology and Biochemistry; Alef, K., Nannipieri, P., Eds.; Academic Press: London, UK, 1995; pp. 335-336.

[33] Araujo, C. L.; Vihko, P. T. (2013). Structure of Acid Phosphatases. Methods Mol. Biol., 1053, 155-166.

[34] Martínez-Carballo, E.; González-Barreiro, C.; Scharf, S.; Gans, O. (2007). Environmental monitoring study of selected veterinary antibiotics in animal manure and soils in Ausria. Environ. Pollut., 148, 570-579. 
[35] Ravindran, B., Mnkeni, P. N. S. (2016). Bio-optimization of the carbon-to-nitrogen ratio for efficient vermicomposting of chicken manure and wastepaper using Eisenia fetida. Environ. Sci. Pollut. Res., 23 (17) (2016), pp. 16965-16976.

[36] Bolan, N. S., A. A. Szogi, T. Chuasavathi, B. Seshadri, M. J.
Rothrock, P. Panneerselvam (2010). Uses and management of poultry litter. World Poult. Sci. J., 66, pp. 673-698.

[37] Kao, P. H., C. C. Huang, Z. Y. Hseu (2006). Response of microbial activities to heavy metals in a neutral loamy soil treated with biosolid, Chemosphere 64, 63-70. 